\title{
Accelerating Qurán Reading Fluency Through Learning Using QURÁNI Application for Students with Hearing Impairments
}

\author{
https://doi.org/10.3991/ijet.v14i06.9863 \\ Yusuf Hanafi $^{(\varpi)}$, Heppy Jundan Hendrawan, Ilham Nur Hakim \\ Universitas Negeri Malang, Malang, Indonesia \\ yusuf.hanafi.fs@um.ac.id
}

\begin{abstract}
The ability to read Qurán of students with hearing impairments supported by special education is still not as expected due to the limited access to technology. The progress of technology such as a smartphone has led many people to adopt a view that the technology of application is very appropriate to be developed for their learning. In this study, we have developed an application called QUR'ANI to teach reading the Qur'an fluently and appropriately for students with hearing impairments. The method used was single subject research with the $\mathrm{AB}$ model. The effectiveness of this application in teaching the Qur'an for students with hearing impairments has been tested with positive effect. Besides, the teacher's subjective point of view in this application has also been consulted. This research found that there was a strong correlation between the components of reading fluency.
\end{abstract}

Keywords-Qur'an, reading fluency, QUR'ANI, hearing impairment

\section{$1 \quad$ Introduction}

Reading the Holy Qur'an is one of the activities that is highly recommended for Muslims. Reading the Qur'an should be done carefully so that there will bo no mistake in pronunciation. The language used in the Qur'an is Arabic. For most nonArabic students including those who are in Indonesia, reading the Qur'an is one of the difficult skills due to their lack of understanding of Arabic in terms of pronunciation [1]. Another problem, student's accent also affects the pronunciation when reading the Qur'an which results in errors in reading [2] [3]. To avoid such problems, Tajweed rules are implemented to ensure reading the Qur'an is done correctly and accurately. In another sense, Tajweed is a rule of how to read the Qur'an fluently. The research conducted by Zarif et al. [1] showed that there is a close relationship between fluency of reading and adherence to the Tajweed rules in reading the Qur'an.

The obligation to learn reading the Qur'an fluently applies to every Muslim [3], including Muslims with hearing impairments. The results of preliminary studies showed that the students with hearing loss had poor Qur'an reading skills. They have not been able to read the Qur'an fluently and precisely. In a different context, the 
research on the reading ability of the students with hearing impairments has been highly conducted. The newest one was reported by Harris \& Terlektsi [4], Miller et. al. [5], Kronenberger et al. [6], and Harris et al. [7]. A number of those researches showed the similar result that the students with hearing loss were difficult in reading. The hearing loss has resulted in communication barriers that limit the students' access to the learning. This case negatively contributes to the reading skill [8], including reading the Qur'an [9].

The condition shown by a number of studies require scientists and educators to find the right approach in developing the reading skill of the students with hearing impairments. Rambeau [10] revealed that today the researchers are demanded to find the answer of how a number of people with hearing loss can actually a good reading skill. In recent years, many researchers have debated how students with hearing impairments can have the ability to read by developing phonological awareness [10] [11] [12]. However, the phonological awareness is said that it is not the only key of the success of the students with hearing loss in developing reading skill [13]. Moreover, Nittrouer et al. [14] and Miller et al. [5] stated that the awareness of word structure is also another key and has a role that is as important as phonological awareness.

In the context of reading the Qur'an, building phonological awareness and word structure to the students with hearing impairments is needed in order they can read the Qur'an fluently in accordance with Tajweed rules. The success of building both awarenesses in improving the Qur'an reading skills for the students with hearing impairments is influenced by some factors such as attitude, passion, motivation, and learning method [3] [15], especially in specific education. However, specific education has not been able to provide various kinds of learning [3] and tends to be conventional [16]. This implemented method has caused the students with hearing impairments difficult to upgrade their skills [17]. The study conducted by Luccas et al. [18] showed that the students supported by specific education had the same level of reading skills to the students unsupported by specific education.

The failure of specific education in developing the ability to read the Qur'an in children with hearing loss is caused by the weak teaching method [9], especially in terms of the availability of very limited technology and assistance tools [15] [16] [62]. In fact, the research conducted by Easterbrooks \& Stephenson [19] 20 methods in effective reading learning for students with hearing impairments reported that the use of technology is the most effective method. Today, many application-based technologies are developed on the smartphone to solve the learning problems for students with hearing impairments [60], but in the context of Qur'an learning is very limited including in Indonesia. Application on the smartphone is continually upgraded since it is regarded as the right assistance technology for students with hearing impairments [20] [21]. The results of research carried out by Çuhadar et al. [22] and $\mathrm{Ng}^{\prime}$ the et al. [23] also showed that the application technology can make the learning level much better for the students with hearing impairments.

In line with a number of the summaries of literature that have been mentioned, this research was undertaken to significantly contribute in Qur'an learning for students with hearing impairments in Indonesia by providing an Android-based application. In 
this research, we focused on how the application that has been developed - QUR'ANI - can help the students with hearing impairments to have the ability to read the Qur'an fluently. As far as we know, the research on the reading fluency for students with hearing impairments is still limited [24], especially in the context of reading the Qur'an. The research and development of the similar application as Fakih [16] has not reported how this android application helps the children with hearing impairments to have the ability to read the Qur'an fluently. This study tried to find the answers to the question of application that has been developed as follow:

- Is the QUR'ANI capable of making students with hearing impairments have better Qur'an reading skills?

- Are students able to maintain the ability to read the Qur'an during the follow-up phase?

- Is the QUR'ANI application developed according to the characteristics and needs of students with hearing impairments according to the subjective evaluation from the teacher? $(d)$ is there a correlation between the components of fluency reading in Qur'an reading learning through the QUR'ANI application?

\section{$2 \quad$ Literature Review}

\subsection{Qur'an reading fluency}

Reading fluency is one of the components in the reading program for children with hearing loss recommended by The National Reading Panel [25] and The National Agenda [26]. Reading fluency is the main characteristic of a good reader. Reading fluency is very necessary for reading and understanding what is read to be successful in life [27]. Meanwhile, Qur'an reading fluency is needed to be able to read the Qur'an without wrong pronunciation [2] [3] and understanding the content of the Qur'an well as the guide of life holistically including the Islamic community life.

Reading fluency is defined as someone's ability to read a text correctly and accurately with the right expression [25] [28] [29]. Reading fluency has been identified as a key component in effective reading learning oriented to the improvement of students' reading understanding [25] [30], especially the students with reading difficulties. Furthermore, Rasinksi et al. [30] explained that reading fluency is often associated with oral reading. Prosodic or expressive reading is only able to observed in oral reading and not able to be examined during silent reading.

Reading fluency consists of three main components namely accuracy, automaticity, and prosody [31] [32]. The measurement of accuracy can be done by counting the percentage of words that are read correctly in oral reading while automaticity is carried out by counting the number of words that are read correctly per 100 words [28] or in the duration of reading for one minute [33]. Meanwhile, prosody is measured with a rubric developed by Rasinksi [33] including a number of elements of prosody or expression. 
Referring to those definitions and measurement, Qur'an reading fluency can be defined as an ability to read Qur'an orally, fluently, and accurately in accordance with Tajweed rules. The measurement of Qur'an reading fluency is undertaken by measuring the needed time in solving a verse in Qur'an and the number of errors in reading the punctuation and word, articulating the Hijaiyah letters and words correctly and fluently, and the mistakes do not follow Tajweed rules as done by Zarif et al. [1].

The main problem of the students with hearing impairments in reading the Qur'an is their inability to pronounce and spell letters and words. Articulation in reciting letters is still unclear and almost the same as the other letters in one classification/group of Hijaiyah letters [34]. The weak working memory has resulted in the ability to comprehend the concept of Arabic as a whole is also low [35]. They need more time to learn letters and words in the Qur'an since the language used is unfamiliar and new to them. In other words, the phonological awareness is the main problem of the children with hearing loss in reading the Qur'an.

\subsection{Qur'an reading learning}

Reading skill is believed as an ability that can be trained and taught. Reading skill will improve when given the right teaching strategy. The researchers have recommended many strategies to improve reading fluency, but most of them lead to the repeated reading method. This strategy is also suggested by The National Reading Panel [25] as the most appropriate way to upgrade the fluency and achievement of reading outcome holistically.

Repeated reading strategy is included in traditional strategies that are highly used in psychological studies and special education. Repeated reading was developed by Samuels [36]. This strategy uses text and is divided in some equal length-parts. This strategy can be started by reading together with the teacher and the students read aloud. This procedure is repeated until reaching the targeted performance. Mioduser [37] explained that this method has a weakness namely the fluency in reading is dominantly caused by the memory of the repeated word/sentence. However, this strategy is considered very suitable for students with hearing impairments that have low working memory and need repeated method [38]. The research on the effectiveness of repeated reading to improve the reading fluency has also been proven from a number of research conducted including Samuels [36] that has tested this strategy to the children encountering reading difficulties with a non-experimental research. Most recently, the meta-analysis of repeated reading strategy for the children with reading difficulties carried out by Lee \& Yoon [39] and the study conducted to the third graders by Marano [40] showed the similar result that this strategy was effective in enhancing reading fluency.

In the Qur'an reading learning, the traditional strategy such as repeated reading has been applied for decades in various public and religious schools in Indonesia. As a result, it has proven to be effective in improving the ability to read the Qur'an of the students with normal hearing. However, inversely proportional to the conditions in specific education, this traditional strategy is believed to have made it increasingly 
difficult for children to learn to read the Qur'an properly [3] [9]. The research conducted by Herlina et al. [41] found that teachers in special education tended to teach verbally without interesting media. As a consequence, the students with hearing impairments have not been able to read Hijaiyah letters. The same result was also shown by Hasan [42] finding that teacher of special need still used lecture method impacting on the less optimal and boring learning.

This result is not in line with the explanations of theory and empirical results stating that repeated strategy is in accordance with the children with hearing impairments. However, the emphasize of the Qur'an learning for children with hearing loss should be on self-factors [3]. In other words, building self-motivation to the students to learn the Qur'an is the main key. Kuhn et al. [29] also said that this strategy is still popular and effective but there is always a need for an additional method. Some researchers recommend providing technology-based learning access as an additional method for children with hearing impairments. In the past few decades, the research carried out by Carver \& Hoffman [43] showed that computer-based repeated reading strategy has a higher effectiveness. Based on such literature, it can be said that Qur'an reading learning for children with hearing impairments will be effective by using technological assistance [9] since it can improve students' motivation more highly [44]. Moreover, the students with hearing impairments have a positive attitude towards technology [45].

\subsection{Application of QUR'ANI}

QUR'ANI comes from the Qur'an Isyarat (sign) - a word in the Indonesian language - in English, it means Sign Language Qur'an. Media in the form of this application is developed to provide assistive technology in accordance with the characteristics and needs of students with hearing impairments in Qur'an reading learning, especially in special education. The application is chosen to be developed for some reasons namely familiar media for students with hearing impairments [46] [47], the high number of users, and it is open source. The other main reason, the mobile application has been proven that it can help to improve the students' motivation [21] in enhancing literacy [48] [44] and it is beneficial in upgrading the cognitive development including in developing Qur'an reading skill [15].

QUR'ANI is designed to provide perceptual information and linguistic information. Both are explained as a factor influencing the reading skill of students with hearing impairments [49]. QUR'ANI was developed by noticing some dimensions of usability of special application for students with hearing impairments referring to Nathan et al. [50]. This application consists of a multimedia component to make the students with hearing impairments can effectively learn. The visual and audio information in this application was balanced to accommodate all learning styles of the students with hearing impairments. Although the audio content is considered not too important, it is believed to be able to reduce students' juggling action during learning [17] and give higher learning access to the students with low hearing impairments. 
On the menu of Hijaiyah, there is a menu of speech to sign language, this content will give higher learning accessibility [51] and it is believed to be able to significantly contribute in the application for the students with hearing impairments [52]. The menu of Juz Amma is also completed with the videos of sign language. This content is an important aspect and should not be overlooked in designing a special application for the students with hearing impairments [53].

Reading is closely related to cognitive development [11], and working memory [54]. Referring to that explanation, the principle of the cognitive theory of multimedia learning applies in reading the Qur'an for students with hearing impairments using QUR'ANI. Multimedia-based learning topic is the most effective way to reduce the learning barriers for students with hearing impairments by considering the principle of combining the technological element of audio, visual, and digital technologies to facilitate the more effective and qualified learning activities of students with hearing impairments [55]. In the principle of multimedia, figures and words are presented in the form of video [56]. In other words, the cognitive theory of multimedia learning states that learning by combining visual and auditory was proven more effective compared to only by visual [57].

\section{Methodology}

The participants in this study consisted of four students including two males and two females with the various ages of 15-18 years old. They were ninth class students. The five participants had (a) the ability to use an Android smartphone, (b) deafness with the hearing loss level between 80-90 db (severe-profound), (c) the low ability to read Hijaiyah letters, and (d) the ability to communicate orally and in sign language. The selection of subjects in secondary school level relied on the research results of Wexler et al. [58] that have identified that the intervention of reading fluency has been proven effective for secondary-level students. The demographic characteristics of the participants are presented in Table 1. The names used in this research were changed to save the participants' privacy.

Table 1. The characteristic of the participant

\begin{tabular}{|l|l|l|l|}
\hline \multicolumn{1}{|c|}{ Subject } & \multicolumn{1}{c|}{ Gender } & \multicolumn{1}{c|}{ Age } & \multicolumn{1}{c|}{ Classification of Deafness } \\
\hline Citra & Female & 17 years & Severe \\
\hline Faniah & Female & 18 years & Profound \\
\hline Hafzdi & Male & 16 years & Severe \\
\hline Jona & Male & 15 years & Severe \\
\hline
\end{tabular}

This study used single-subject research with AB model. Independent variable (IV) in this research was QUR'ANI application developed to teach Qur'an reading for students with hearing impairments. The dependent variable in this research was the ability to read Qur'an fluently. This research was conducted in one of special education school in Malang City. Every meeting of learning was undertaken by using Android with a 5-6 inch screen and earphone with the learning format of one-to-one teaching between 08.00-12.00 o'clock. 
The procedure of this research consisted of three main stages namely baseline, intervention, and follow-up sessions. The students and teacher meet in the same place, time, and duration routinely every day during research. In the first 10-15 minutes in each meeting session, the teacher reviews the lesson learned in the previous meeting. The next 30-45 minutes were used to conduct a teaching in accordance with the research plan. The last 10-15 minutes were used to assess the ability to read Qur'an using Iqra and Qur'an (printed), but the assessment was not done every day, only the third day (Wednesday) and the sixth (Saturday) in every week.

In the baseline and follow-up phases, the teaching was done by using a strategy usually used (instruction-as-usual) in the school. During the intervention phase, the teacher taught QUR'ANI application installed in the android of each participant. The intervention phase was begun by training session by using QUR'ANI application for the students with the following steps:

- The teacher gave a direct example of how to use the application

- The students were asked to directly try the application in each android

- The teacher gave feedback especially the errors that might still occur in the application usage.

In the initial intervention phase, the teacher motivated by explaining the essence of reading Qur'an fluently. During the intervention session, the teacher accompanied the students in learning reading Hijaiyah letters and short Surah in the Qur'an using QUR'ANI. In the last session of intervention, the teacher reviewed the learning process that has been done (conducted except the day of assessment). Follow-up phase was carried out to know whether the students maintain the performance of the ability to read the Qur'an after a break of learning using QUR'ANI. The follow-up phase was undertaken about two weeks after the last session in the intervention phase.

In this research, the data for effectiveness and reliability were collected. The data of effectiveness were gathered by measuring the number of Hijaiyah letters pronounced in one minute and words that could be read in one minute for surah Alfatihah. The first measurement was used to know the accuracy while the second measurement was employed to know automaticity. In this research, the third component of reading fluency was measured. The selection of accuracy and automaticity was because both components were considered the most basic problem in the skill of reading Qur'an for students with hearing impairments. Rasinksi [59] explained that both of them were the main measurement of reading fluency. The research procedure was undertaken by doing the following setting. In the baseline phase, at least five sessions of measurement were executed to each participant. The baseline phase would be continued if the data showed stability or at least improvement. In the intervention phase, at least nine sessions of measurement for each participant. The intervention phase was ended when at least two participants showed the stable data or tendency of improving data. The follow-up phase was carried out with twice measurement.

The data measurement and recording were manually conducted, and the standard of students' uncertain answers (the students were stated as right if they read the letters/word clearly enough heard by the observer and better than the previous phase) 
threated the data reliability. In this research, the occurrence agreement from three observers was calculated to maintain the reliability of the collected data. The occurrence agreement was calculated through agreement/ agreement + disagreement $x$ 100. The result of occurrence agreement showed above the target $>75 \%$, meaning that the data were reliable.

The social validity of QUR'ANI application was evaluated by accepting the teacher's subjective perspective. To measure the social validity, the researchers interview the teacher before the baseline phase and the last session of follow-up. Besides, the measurement was also done by using a questionnaire consisting of five questions with the Likert 5-point scales.

To determine whether QUR'ANI application could improve the ability to read the Qur'an of students with hearing impairments in this research, a visual analysis was carried out as recommended Kratochwill et al. [65]. The split-middle method was used in analyzing the condition including level, tendency, and variability of the data for each dependent variable. Besides, descriptive statistic calculation was also done including median, mean, and standard deviation (SD) for each phase. The last, the overlap was checked by calculating the percentage of nonoverlapping data (PND) point between baseline and intervention phase, and the percentage of intervention data point exceeded the media of baseline phase (PEM).

This study also carried out linear regression statistic analysis between two dependent variables namely accuracy and automaticity [66]. Many experts state that both of them are the basic foundation of reading fluency but the research of the relationship of both of them has not been widely studied. This relationship should be found to answer the evaluation question from QUR'ANI application whether two main measurements of reading fluency have a strong relationship in Qur'an reading learning using QUR'ANI. This answer is important to explain that the application developed can develop both measurements simultaneously.

\section{$4 \quad$ Results and Discussion}

The data of the number of Hijaiyah letters read correctly showing the accuracy in reading the Qur'an in all research stages for each participant are presented in Figure 1, 2,3 , and 4. Meanwhile, the data of the number of words that could be read properly in Surah Al-Fatihah showing the automaticity in reading the Qur'an is shown in Figure 5, 6, 7, and 8. Median, mean, SD, PND, and PEM in the aspect of accuracy and automaticity are presented in Table 2 and 3.

\subsection{Accuracy}

The mean and median during baseline phase of the first student, Citra, were at the level of 13.1 and 13.5. The data in the baseline phase was relatively stable and showed an increasing trend. The accuracy in reading the Qur'an during the intervention phase also showed the same result that was stable and increasing with the 
mean of 21.0. The follow-up phase also enhanced from 22 to 24 (Figure 1). PEM and PND for Citra were Citra 100\% (Table 2), respectively.

The second student, Faniah, reached the mean and median in the baseline phase of 12.3 and 12.5, slightly lower than Citra. The data in the baseline phase showed stable and increased. The data in the intervention phase showed variable (unstable) but still showed an increase from 14 to 24 with the mean of 19.6. The follow-up phase showed a horizontal trend, one number below the highest number in the intervention phase namely 23 (Figure 2). PEM and PND were at the percentage of 100\% (Table 2).

The third student, Hafdzi, the tendency of data stability in baseline and intervention phases was similar to Faniah namely from stable to variable. However, both baseline and interventions phases showed the estimation of positive tendency. The mean in baseline phase was 11.7 and increased again in the intervention phase with the mean of 18.3. in the follow-up phase, the mean decreased from 21 to 20, only reduced one number and did not return to the baseline level (Figure 3). PEM and PND were at a percentage of $100 \%$ and $91.7 \%$ (Table 2 ).

The fourth student, Jona, had the tendency of data stability in baseline and intervention phases showing the similar result to Citra namely from stable to stable that tended to the positive direction and the follow-up phase also showed the same thing. The mean in baseline phase was slightly lower than that of Citra namely 11.7 but the mean in the intervention phase was 26, the highest among the other students and the follow-up phase showed the same thing. (Figure 4). PEM and PND were in the percentage of $100 \%$ (Table 2 ).

\subsection{Automaticity}

The first student, Citra had the mean and median during the baseline phase of 1.3 and 1.0, respectively. The mean and median in the intervention phase were 7.5 and 8.0 , respectively. In the initial five data of the baseline phase, the data point tended to be horizontal and the increase in the last point. The analysis between conditions showed that the change of orientation and positive effect, and the change of stability from stable to stable. The follow-up phase showed an increase as well (Figure 5). PEM and PND were $100 \%$ and $91.7 \%$, respectively (Table 3).

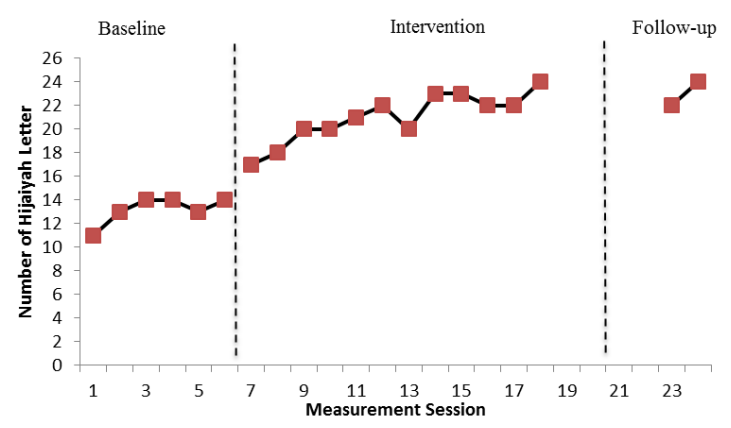

Fig. 1. Citra's accuracy in all sessions 
Paper-Accelerating Qur'an Reading Fluency Through Learning Using QUR'ANI Application ...

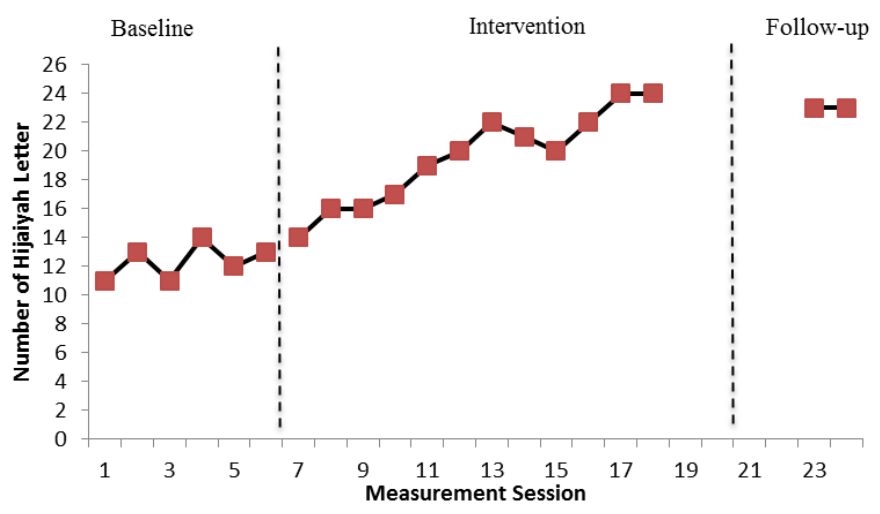

Fig. 2. Faniah's accuracy in all sessions

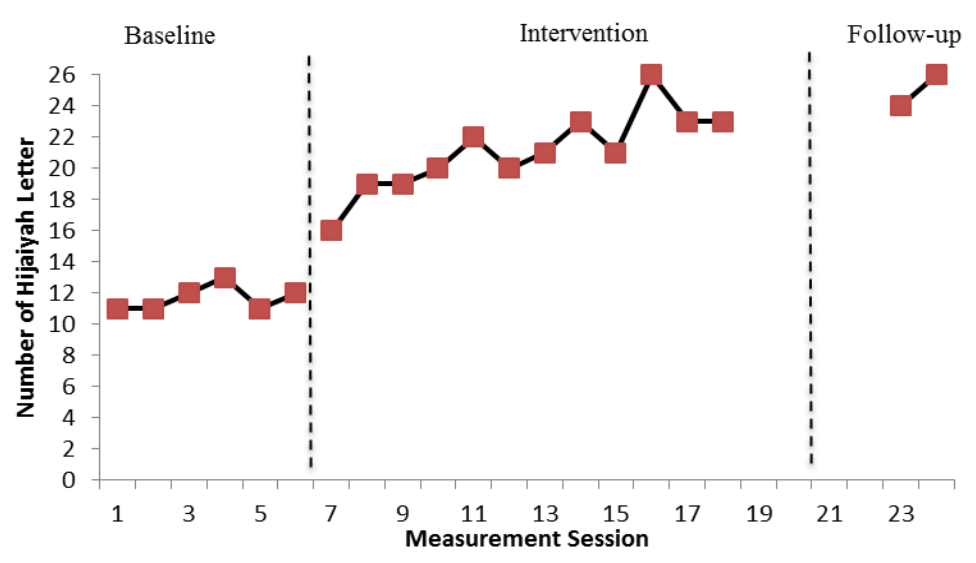

Fig. 3. Hafzdi's accuracy in all sessions

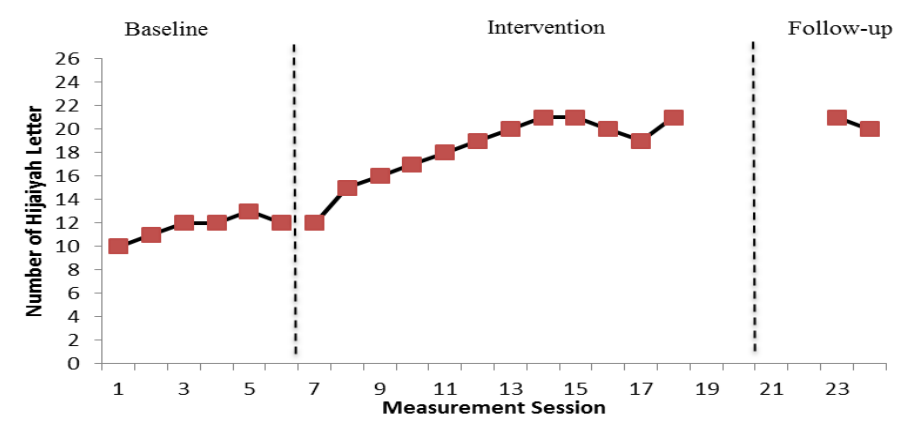

Fig. 4. Jona's accuracy in all sessions 
Table 2. Accuracy data point

\begin{tabular}{|l|c|c|c|}
\hline \multicolumn{1}{|c|}{ Student } & Baseline & Intervention & Follow-up \\
\hline Citra & & & 23 \\
Median & 13.5 & 21.5 & $23(1.4)$ \\
Mean (SD) & $13.1(1.2)$ & $21.0(2.1)$ & \\
PND & & $100 \%$ & \\
PEM & & $100 \%$ & 23.0 \\
\hline Faniah & 12.5 & 20.0 & 23.0 \\
Median & $12.3(1.2)$ & $19.6(3.3)$ & \\
Mean & & $100 \%$ & \\
PND & & $100 \%$ & 20.5 \\
PEM & 12.0 & 19.0 & $20.5(0.7)$ \\
\hline Hafzdi & $11.7(1.0)$ & $18.3(2.9)$ & \\
Median & & $91.7 \%$ & \\
Mean & & $100 \%$ & 25.0 \\
PND & & & 21.0 \\
PEM & 11.5 & $21.1(2.6)$ & \\
\hline Jona & $11.7(0.8)$ & $100 \%$ & \\
Median & & $100 \%$ & \\
Mean & & & \\
PND & & & \\
PEM & & & \\
\hline
\end{tabular}

Table Note. PND $=$ Percentage of nonoverlapping data point between baseline dan intervention phases. $\mathrm{PEM}=$ Percentage of intervention data point above the median of baseline.

The second student, Faniah, had the mean and median in the baseline phase higher than the other students namely 2.5 and 2.5 , respectively. However, in the baseline phase, the tendency of stability showed variable, this phase was ended and continued with the intervention phase since the estimation of the tendency showed positive. The mean in the intervention phase was 8.9, the highest one among the other students, but the change of level was still in the lower condition compared to Citra. The follow-up phase showed the estimation of the tendency to the horizontal direction in the number of 9 (Figure 6). PEM and PNS were 100\%, respectively (Table 3).

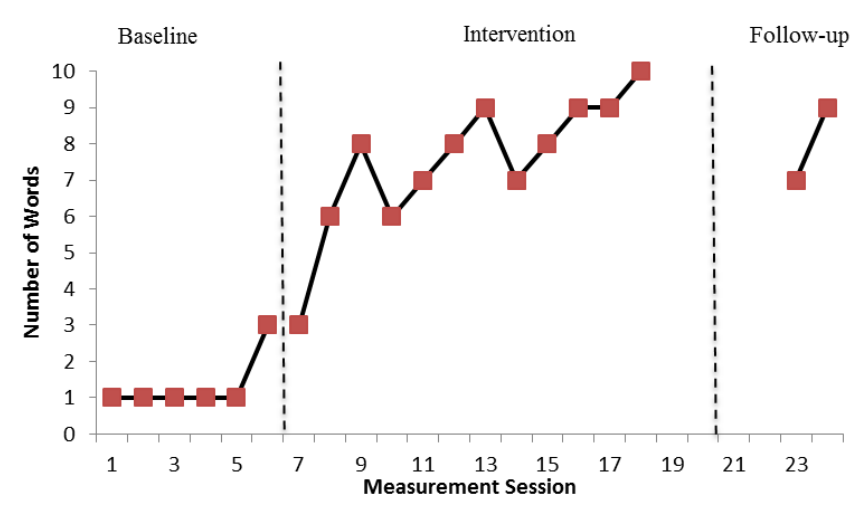

Fig. 5. Citra's automaticity in all sessions 
The third student, Hafzdi, in the baseline phase showed the variable stability tendency with the mean and median of 1.0 and 1.0. These data points were the lowest among the other students in the same phase. The baseline phase was ended after the estimation of the tendency showed positive or increase. The follow-up phase showed the estimation of the tendency to be horizontal, similar to the condition of Faniah but it was in the number of 7 (Figure 7). Each PEM and PND were 100\% and 91.7\% (Table 3).

The fourth student, Jona, in the baseline and intervention phases showed the change of stability from stable to stable, and the orientation change and positive effect, the similar condition to Citra's. the mean and median in the intervention phase was...the follow-up phase also showed the condition increasing from 8 to 10, the highest number in the intervention phase (Figure 8). PEM and PND were 100\% and $91.7 \%$ (Table 3 ).

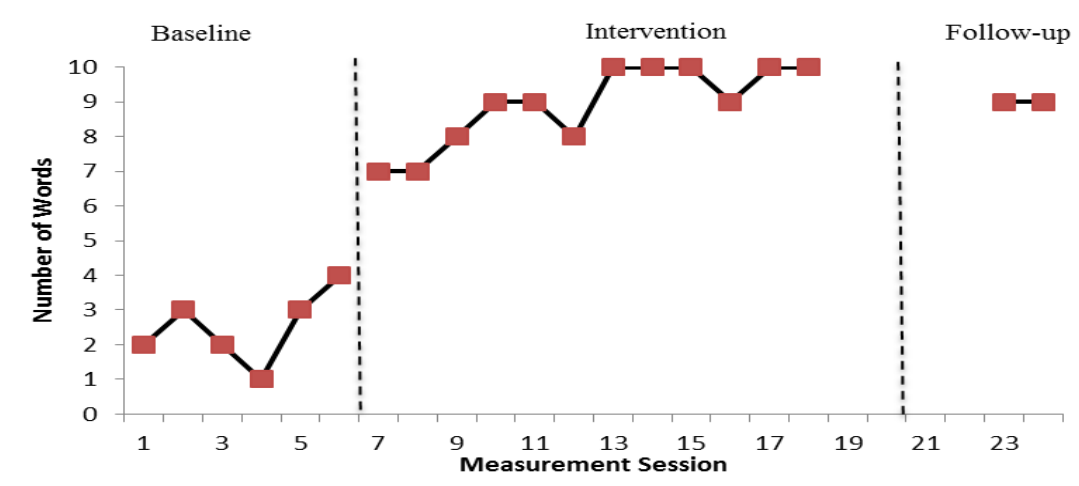

Fig. 6. Faniah's automaticity in all sessions

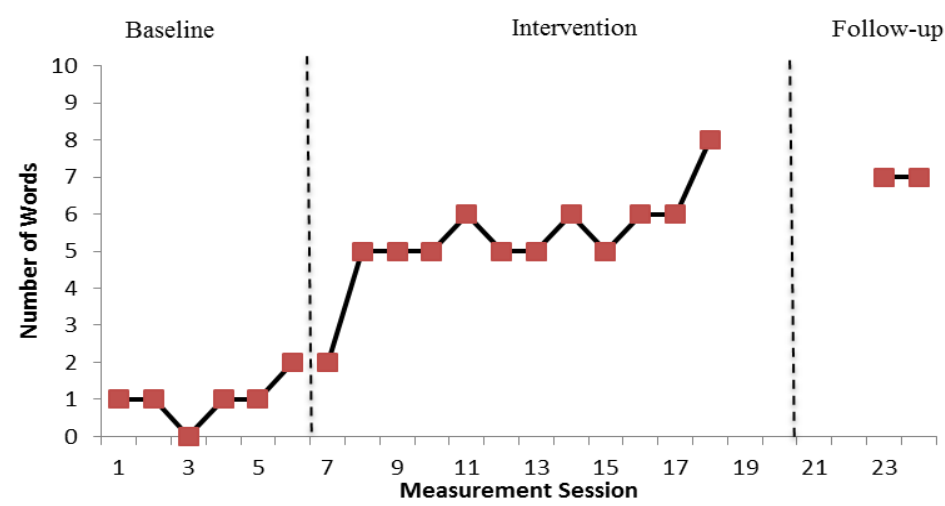

Fig. 7. Hafzdi's automaticity in all sessions 


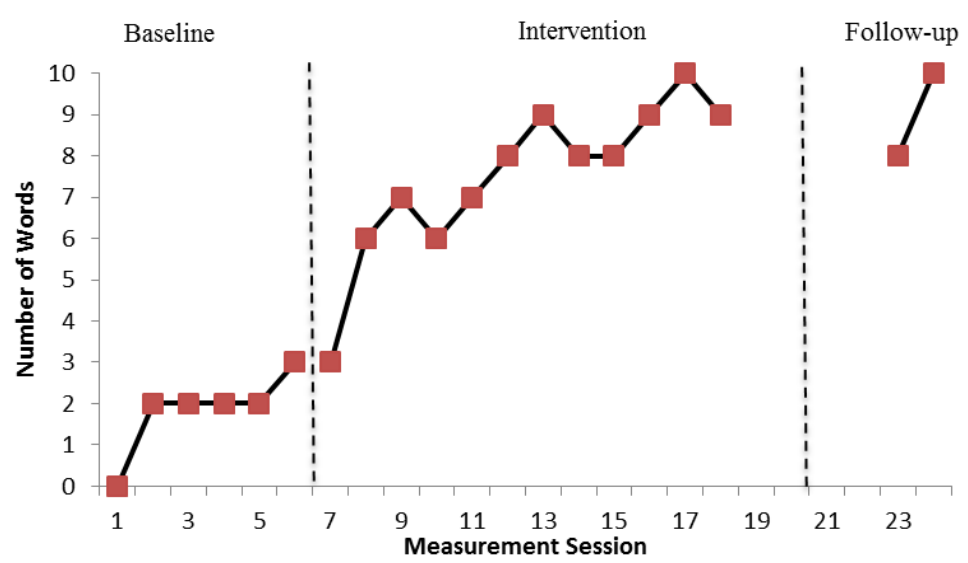

Fig. 8. Jona's automaticity in all sessions

Table 3. Automaticity data point

\begin{tabular}{|l|c|c|c|}
\hline \multicolumn{1}{|c|}{ Student } & Baseline & Intervention & Follow-up \\
\hline Citra & & & 8.0 \\
Median & 1.0 & 8.0 & $8.0(1.4)$ \\
Mean & $1.3(0.8)$ & $7.5(1.9)$ & \\
PND & & $91.7 \%$ & $100 \%$ \\
PEM & & & 9.0 \\
\hline Faniah & 2.5 & 9.0 & 9.0 \\
Median & $2.5(1.1)$ & $8.9(1.2)$ & \\
Mean & & $100 \%$ & \\
PND & & $100 \%$ & 7.0 \\
PEM & 1.0 & 5.0 & 7.0 \\
\hline Hafzdi & $1.0(0.6)$ & $5.3(1.4)$ & \\
Median & & $91.67 \%$ & \\
Mean & & $100 \%$ & 9.0 \\
PND & & 8.0 & $9.0(1.4)$ \\
PEM & 2.0 & $7.5(1.9)$ & \\
\hline Jona & $1.8(1.0)$ & $91.67 \%$ & \\
Median & & $100 \%$ & \\
Mean & & & \\
PND & & & \\
PEM & & & \\
\hline
\end{tabular}

$\mathrm{PND}=$ Percentage of nonoverlapping data points between baseline and intervention phases. $\mathrm{PEM}=$ Percentage of the data point in the intervention phase above the median of baseline phase.

\subsection{Social validity data}

Social validity was obtained from interview and questionnaire given to the teacher especially in the last part of the research. This scale questionnaire was filled by four teachers of the participants given the chance to learn using application. The results of the questionnaire are presented in Table 4 . The mean of the aspect of satisfaction and 
multimedia was 4.5 while the aspect of the easiness, goal, and recommendation of usage was 4.7 . the mean of all aspects was 4.5 out of 5 . The data analysis of the questionnaire results was added with the interview results revealing that teacher responded and gave positive attitude towards QUR'ANI and the intervention results. In general, teacher considers that QUR'ANI application is very suitable for students with hearing impairments since the device is familiar and liked by the students and makes them highly motivated to learn. This case is regarded as the most important thing in learning.

Table 4. The social validity scale for the teacher of the hearing-impaired student

\begin{tabular}{|c|l|c|}
\hline Question number & \multicolumn{1}{|c|}{ The items of the scale } & Average \\
\hline 1 & $\begin{array}{l}\text { Do you feel satisfied with the } \\
\text { QUR'ANI application developed } \\
\text { for students with hearing } \\
\text { impairments? }\end{array}$ & 4.5 \\
\hline 2 & $\begin{array}{l}\text { Can QUR'ANI application be } \\
\text { easily operated by students with } \\
\text { hearing impairments? }\end{array}$ & 4.7 \\
\hline 3 & $\begin{array}{l}\text { In your opinion, can this } \\
\text { application help the ability to read } \\
\text { Qur'an of the students with hearing } \\
\text { impairments? }\end{array}$ & 4.7 \\
\hline 4 & $\begin{array}{l}\text { In your opinion, are the } \\
\text { components of multimedia and } \\
\text { contents of QUR'ANI application } \\
\text { very suitable for the need of } \\
\text { students in reading the Qur'an? }\end{array}$ & 4.5 \\
\hline 5 & $\begin{array}{l}\text { Will you recommend the teacher in } \\
\text { the other school to use this } \\
\text { application? }\end{array}$ & 4.7 \\
\hline
\end{tabular}

The social validity data from the interview result revealed more the teacher's perception on the progress of the ability to read the Qur'an faster using QUR'ANI application. Apart from the number of hijaiyah letters that have not reached the maximum number and word in Surah Al-Fatihah that tends to be still a half of the maximum number, the teacher stated that the reading speed and articulation accuracy were far better than the initial condition. Towards the end of the intervention phase (the $18^{\text {th }}$ measurement), there were three teachers who commented.

Teacher A commented: "Once students were introduced to the QUR'ANI application, they looked curious to use it immediately. When they used this application, from the way they learned, they seemed to like it very much, they also said so, I think the simple not complicated design of the application has made them very easy in using the application."

Teacher B commented: "The effectiveness of QUR'ANI in helping the students with high hearing impairments was inseparable from the interface simply and interestingly designed, the students easily entered and exited from and to the main 
menu, the needed time to solve the number of material in this application is also short, this avoids students from feeling bored."

Teacher C commented: "I feel that students did not experience significant difficulty when using this application, the component of multimedia also supports the material delivered specially for the children with hearing impairments as speech to text and sign language, it is very helpful for them, and of course enhances their accessibility in learning, I think they are quite satisfied with learning by using QUR'ANI'.

\subsection{Correlation between accuracy and automaticity}

ANOVA test results in linear regression (Table 5) showed that the score of $\mathrm{F}=$ 298.062 with a significant value of 0.000 . It means that there was a strong relationship between automaticity and accuracy. The regression test resulted in the score of the correlation coefficient $(R)$ of 0.890 with the reliability value $(R 2)$ of 0.793 . This case means that the contribution given by automaticity to accuracy was $79.3 \%$, while $20.7 \%$ was estimated from the other factors. The regression test also resulted in regression equation namely $\mathrm{Y}=10.645+1.277 \mathrm{X}$ (Figure 9), with the correlation coefficient of scientific literacy ability of 0.793 . These results showed that automaticity highly contributed to the accuracy of reading fluency.

Table 5. Correlation between automaticity and accuracy of reading fluency

\begin{tabular}{|c|c|c|c|c|c|c|c|c|c|}
\hline \multicolumn{2}{|c|}{ ANOVA } & \multicolumn{2}{c|}{$\begin{array}{c}\text { Modal } \\
\text { Summary }\end{array}$} & \multicolumn{2}{c|}{$\begin{array}{c}\text { Regression Coefficient } \\
\text { (Constant) }\end{array}$} & \multicolumn{3}{c|}{$\begin{array}{c}\text { Regression Coefficient } \\
\text { (Automaticity) }\end{array}$} \\
\hline $\boldsymbol{F}$ & $\boldsymbol{p}$ & $\boldsymbol{R}$ & $\boldsymbol{R}^{\mathbf{2}}$ & Beta & $\boldsymbol{t}$ & $\boldsymbol{P}$ & Beta & $\boldsymbol{T}$ & $\boldsymbol{P}$ \\
\hline 298.602 & 0.000 & .890 & 0.793 & 10.645 & 22.093 & 0.000 & 1.277 & 17.280 & 0.000 \\
\hline
\end{tabular}

- Predictors: (Constant), Automaticity

- Dependent Variable: Accuracy

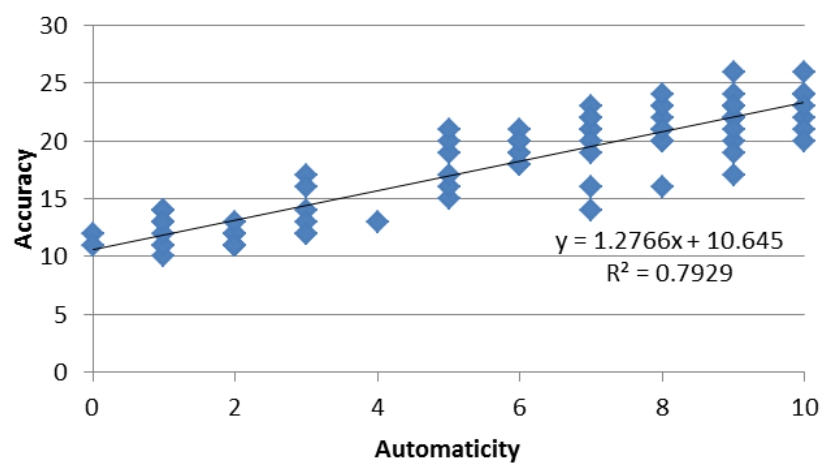

Fig. 9. Correlation between automaticity and accuracy of reading fluency 


\subsection{Discussion}

The visual analysis results showed that the mean increased from the baseline phase to the intervention phase, despite the variable stability tendency for a number of subjects. However, the overall baseline and intervention phases showed the estimation of the tendency of the increasing orientation that can be seen from the score of mean in each phase. It means that there was a change process between the conditions to the positive direction from the aspect of accuracy and automaticity. The follow-up phase also showed the increasing trend in general although there were some horizontal tendencies even decrease it did not return to the same level in the baseline phase. This condition showed that the Qur'an reading material using QUR'ANI could be well maintained by the students. This result also showed that there was a functional relationship between Qur'an reading learning using the QUR'ANI application as a variable independent with Qur'an reading fluency as a variable dependent, and this relationship was successfully described by a single subject research especially with $\mathrm{AB}$ model design.

The analysis has identified that QUR'ANI application developed for the students with hearing impairments was effective in improving Qur'an reading fluency, especially from the measurement of accuracy and automaticity components. The teacher's point of view also showed a positive attitude that QUR'ANI is believed that it is very helpful for the students with hearing impairments to have a better skill in reading the Qur'an. This finding is directly proportional to various works of literature that have been mentioned that Qur'an learning using technology especially Androidbased application was effective for the students with hearing impairments especially in building a higher learning motivation.

Some explanations that should be emphasized regarding the effectiveness of QUR'ANI in accelerating the Qur'an reading fluency of the children with hearing impairments are as follow. From the aspect of participants, it was found that they did not tend to communicate not only by oral or in sign language, but also by both ways. this case could help effective communication between teacher and students in guiding the students in using the application. Besides, the interaction of students with the application run better since this application provides not only the menu with sign language as communication but also the menu with a speech to text utilizing the ability to communicate orally. This result is in line with the explanation given by Luccas et al. [18] that good communication with the students is an essential aspect in learning of students with hearing impairments. The students that could totally communicate will reduce the barriers of communication in the learning. The values of the data point in the intervention were relatively not varied between the participants although there was a difference in the tendency of stability this result indicated that there was no significant communication gap in the learning process by using QUR'ANI application.

From the aspect of the application, the special contents for students with hearing impairments such as video sign language and speech to text as mentioned before became the main factors. Speech to text can be applied as a self-learning method for the students with hearing impairments [61]. In this application, all voice sources were 
transcripted so that people with hearing loss could access it [64]. The video in the menu of Juz Amma will assist the students to read since it is completely transcripted. Speech to text also can help to develop the phonological awareness - explained as the main factor in building reading skill since it facilitates the students to spell and pay attention to letters/words [63].

During the process of research, the students with hearing impairments given intervention did not find many difficulties. Confusion and errors in using the application were rare and they happened only in the initial phase of the intervention. This case is understandable since the students needed the time to use it well. This result was also inseparable from the development that really emphasizes the usability aspect from the interface to communication way used in the application. From the result of social validity from both questionnaire and interview, the QUR'ANI application has fulfilled the usability requirements stated by Nathan et al. [50].

This research also found a strong correlation between the component of automaticity and accuracy in Qur'an reading fluency. This result indicated that Qur'an reading learning using this application could improve both main components of reading fluency simultaneously and in parallel. Kuhn et al. [29] addressed that the introduction of word automaticity reflects the ability to read the words in the text with not only accuracy but also minimum cognitive effort. Besides, this result has proven the good enough result consistency.

The improvement of Qur'an reading skill for all participants showed that they who had low ability to read Qur'an could obtain the benefits from Qur'an learning using QUR'ANI application. The teachers who participated in this research also stated that they attained the meaningful scores of how to design a learning in accordance with their students' characteristics. From this result, this research is considered to have been able to provide theoretical and practical implications of how to develop the Android-based application for the students with hearing impairments which is appropriate and proper especially in the context of Qur'an reading.

This research has been identified that it could provide a wider opportunity to the children with hearing loss in building the Qur'an reading fluency. It will possibly match the skill of children with normal hearing when given a longer period of time. It is estimated that this research also contributes to providing sufficient technology or assistance tools for Qur'an reading learning in special education in Indonesia. The provision of appropriate and sufficient multimedia in accordance with the characteristics and needs believed to be able to make the learning goal can be achieved faster as the literature has been explained. Besides, this research also high potentially contributed to national and international literature in terms of evaluation of the efficiency of Qur'an reading learning using application through single-subject research by paying attention to the subject's characteristic, in this research the subjects were the children with hearing impairments.

Nevertheless, in the review, a number of aspects of this research design have limitations. The measurement and recording of data of the ability to read Qur'an manually as done in this research are indeed commonly used. However, for further research, it is necessary to formulate and design better measurement and provide more reliable data. Besides, this research only measured both main components; the 
prosody has been explored, how this component can be developed in the application as well. This case opens an opportunity for future research to explore reading fluency more comprehensively. However, it should be emphasized that the third component is better explored after both main components are sufficiently mastered by the participants.

Single subject research methodology is often used to know the effectiveness of an intervention to heterogenous subjects and low incidents. Although the results of this research showed considerable effectiveness this result cannot be directly used to draw a conclusion that this application could improve the ability to read Qur'an in a relatively short time for all students with hearing impairments in the other special education. A research in a longer time is needed to result in more concise research conclusion. Thereby, future research is necessary to extend the duration of intervention, for example in a minimum period of 6 months with multiple baseline designs.

As the result of experience gained throughout the research, the suggestion that might be very important for future research in terms of conducting research are teachers should actively involved in research process especially how to design, implement, and evaluate learning by using technological assistance in the form of application such as this. For the students who are unfamiliar with technology should be given more chances to practice. This case is important so that they can achieve maximum results from the start of the intervention.

\section{Conclusion}

The research findings showed that:

- QUR'ANI application could make the students with hearing impairments have better Qur'an reading skill shown by the mean in the intervention phase that was higher than in baseline phase for all participants

- The participants also could maintain the Qur'an reading skill during follow-up phase although there was a decrease but it was far above the condition in baseline phase

- QUR'ANI application developed in accordance with the characteristics and needs of students with hearing impairments according to the teacher's subjective evaluation obtained from social validity

- There was a positive and strong correlation between the components of fluency reading namely automaticity and accuracy in Qur'an reading learning through QUR'ANI application.

\section{Acknowledgement}

We are grateful to the school, teachers, and students who participated in this research. This research is supported by the Institute of Research and Community Services of the State University of Malang (Universitas Negeri Malang). 


\section{$7 \quad$ References}

[1] Zarif, M. M. M., Mohamad, N. and Bakar, B. A. (2014) Assessing Quranic Reading Proficiency in the j-QAF Programme. Int. Educ. Stud., vol. 7, no. 6, pp. 1-8. https://doi.org/10.5539/ies.v7n6p1

[2] Muhammad, W. M. (2012). EHafiz: Intelligent System to Help Muslims in Recitation and Memorization of Quran. Life Sci. J., vol. 9, no. 1, pp. 534-541.

[3] Saari, N. H. (2012). Factors Affecting the Learning of the Holy Quran among Severely and Profoundly Hearing-Impaired Children with a Cochlear Implant," IOSR J. Humanit. Soc. Sci., vol. 2, no. 1, pp. 85-92. https://doi.org/10.9790/0837-0218592

[4] Harris M. and Terlektsi, E. (2011). Reading and Spelling Abilities of Deaf Adolescents With Cochlear Implants and Hearing Aids," J. Deaf Stud. Deaf Educ., vol. 16, no. 1, pp. 24-34. https://doi.org/10.1093/deafed/enq031

[5] Miller P. et al. (2012). Factors Distinguishing Skilled and Less Skilled Deaf Readers: Evidence From Four Orthographies. J. Deaf Stud. Deaf Educ., vol. 17, no. 4, pp. 439-462. https://doi.org/10.1093/deafed/ens022

[6] Kronenberger, W. G., Colson, B. G., Henning, S. C. and Pisoni, D. B. (2014). Executive Functioning and Speech-Language Skills Following Long-Term Use of Cochlear Implants. J. Deaf Stud. Deaf Educ., vol. 19, no. 4, pp. 456-470. https://doi.org/10.1093/deafed/enu011

[7] Harris, M., Terlektsi, E. and Kyle, F. E. (2017). Concurrent and Longitudinal Predictors of Reading for Deaf and Hearing Children in Primary School. J. Deaf Stud. Deaf Educ., vol. 22, no. 2, pp. 233-242. https://doi.org/10.1093/deafed/enw101

[8] Benedict, K. M., Rivera, M. C. and Antia, S. D. (2015). Instruction in Metacognitive Strategies to Increase Deaf and Hard-of-Hearing Students' Reading Comprehension," J. Deaf Stud. Deaf Educ., vol. 20, no. 1, pp. 1-15. https://doi.org/10.1093/deafed/enu026

[9] Ishak, H. (2016). Methods of Teaching al-Quran to The Hearing Disability Children. p. 7.

[10] Rambeau, J. (2015). Bridging Theories of Phonological Awareness for Deaf and Hard of Hearing Children: Perspectives from Verbotonal Specialists in the United States. Honors Theses, no. 2587.

[11] Magee, P. M. (2014). Challenges with Literacy Development in Children who are Deaf or Hard of Hearing. Res. Pap., no. 509.

[12] Miller, E. M., Lederberg, A. R. and Easterbrooks, S. R. (2013). Phonological Awareness: Explicit Instruction for Young Deaf and Hard-of-Hearing Children. J. Deaf Stud. Deaf Educ., vol. 18, no. 2, pp. 206-227. https://doi.org/10.1093/deafed/ens067

[13] Mayberry, R. I., del Giudice, A. A. and Lieberman, A. M. (2011). Reading Achievement in Relation to Phonological Coding and Awareness in Deaf Readers: A Meta-analysis," J. Deaf Stud. Deaf Educ., vol. 16, no. 2, pp. 164-188. https://doi.org/10.1093/deafed/enq049

[14] Nittrouer, S., Caldwell, A., Lowenstein, J. H., Tarr, E. and Holloman, C. (2012). Emergent Literacy in Kindergartners With Cochlear Implants. Ear Hear., vol. 33, no. 6, pp. 683-697. https://doi.org/10.1097/AUD.0b013e318258c98e

[15] Ghadim N. A. et al., (2013). Mother's Perspective Toward al-Quran Education for Hearing Impaired Children in Malaysia. vol. 1, no. 4, p. 5.

[16] Hussain, A., Jomhari, N., Kamal, F. M. and Mohamad, N. (2014). "mFakih: Modelling Mobile Learning Game to Recite Quran for deaf Children,” Int. J. Islam. Appl. Comput. Sci. Technol., vol. 2, no. 2, pp. 8-15.

[17] Shepherd C. M. and Alpert, M. (2015). Using Technology to Provide Differentiated Instruction for Deaf Learners. J. Instr. Pedadogies, vol. 16, no. July, pp. 1-7. 
Paper-Accelerating Qur'an Reading Fluency Through Learning Using QUR'ANI Application ...

[18] Luccas, M. R. Z., Chiari, B. M. and de Goulart, B. N. G. (2012). Compreensão de leitura de alunos surdos na rede regular de ensino. J. Soc. Bras. Fonoaudiol., vol. 24, no. 4, pp. 342-347. https://doi.org/10.1590/S2179-64912012000400009

[19] Easterbrooks S. and Stephenson, B. (2006). An Examination of Twenty Literacy, Science, and Mathematics Practices Used to Educate Students Who Are Deaf or Hard of Hearing. Am. Annu. Deaf., vol. 151, no. 4, pp. 385-397. https://doi.org/10.1353/aad.2006.0043

[20] Cumming T. M. and Draper Rodríguez, C. (2017). A Meta-Analysis of Mobile Technology Supporting Individuals With Disabilities. J. Spec. Educ., vol. 51, no. 3, pp. 164-176. https://doi.org/10.1177/0022466917713983

[21] Yue W. S. and Zin, N. A. M. (2013). Voice Recognition and Visualization Mobile Apps Game for Training and Teaching Hearing Handicaps Children," Procedia Technol., vol. 11, pp. 479-486. https://doi.org/10.1016/j.protcy.2013.12.218

[22] Çuhadar, C., Odaba, H. F. and Kuzu, A. (2009). m-Learning for Hearing Impaired Learners: Dimensions of Evaluation. Int. J. Educ. Inf. Technol., vol. 3, no. 3, pp. 170-186.

[23] Ng'ethe, G. G., Blake, E. H. and Glaser, M. (2015). SignSupport: A Mobile Aid for Deaf People Learning Computer Literacy Skills. pp. 501-511. https://doi.org/10.5220/0005442305010511

[24] Luckner J. L. and Urbach, J. (2012). Reading Fluency and Students Who Are Deaf or Hard of Hearing: Synthesis of the Research. Commun. Disord. Q., vol. 33, no. 4, pp. 230 241. https://doi.org/10.1177/1525740111412582

[25] The National Reading Panel. (2000). Report of the National Reading Panel: Teaching Children to Read-- An Evidence-based Assessment of the Scientific Research Literature on Reading and its Implications for Reading Instruction. MD: National Institute for Literacy, Jesup.

[26] National Agenda. (2005). Using The National Agenda: Moving Forward on Achieving Educational Equality for Deaf and Hard of Hearing Students. National Deaf Education Project Now, Austin.

[27] Connor, et al. C. M. (2011). Testing the Impact of Child Characteristics $\times$ Instruction Interactions on Third Graders' Reading Comprehension by Differentiating Literacy Instruction. Read. Res. Q., vol. 46, no. 3, pp. 189-221.

[28] Hudson, R. F., Lane, H. B. and Pullen, P. C. (2005). Reading Fluency Assessment and Instruction: What, Why, and How? Read. Teach., vol. 58, no. 8, pp. 702-714. https://doi.org/10.1598/RT.58.8.1

[29] Kuhn, M. R., Schwanenflugel, P. J., Meisinger, E. B., Levy, B. A. and Rasinski, T. V. (2010). Aligning Theory and Assessment of Reading Fluency: Automaticity, Prosody, and Definitions of Fluency. Read. Res. Q., vol. 45, no. 2, pp. 230-251. https://doi.org/10.1598/RRQ.45.2.4

[30] Rasinski, T., Jay Samuels, S., Hiebert, E., Petscher, Y. and Feller, K. (2011). The Relationship Between a Silent Reading Fluency Instructional Protocol on Students' Reading Comprehension and Achievement in an Urban School Setting. Read. Psychol., vol. 32, pp. 75-97. https://doi.org/10.1080/02702710903346873

[31] Valencia, S. W., Smith, A. T., Reece, A. M., Li, M., Wixson, K. K. and Newman, H. (2010). Oral Reading Fluency Assessment: Issues of Construct, Criterion, and Consequential Validity. Read. Res. Q., vol. 45, no. 3, pp. 270-291. https://doi.org/10.1598/RRQ.45.3.1

[32] Yildiz, M., Yildirim, K., Ates, S., Rasinski, T., Fitzgerald, S. and Zimmerman, B. (2014). The Relationship Between Reading Fluency and Reading Comprehension in Fifth-Grade Turkish Students. Int. J. Sch. Educ. Psychol., vol. 2, no. 1, pp. 35-44. https://doi.org/10.1080/21683603.2013.854187 
[33] Rasinski, T. (2004). Creating Fluent Readers. Educ. Leadersh., vol. 61, no. 6, p. 46.

[34] Adriana, I. (2018). Kemampuan Artikulasi Bunyi pada Anaka Tunarungu (Studi Kasus di SLB Negeri Sampang). NUANSA J. Penelit. Ilmu Sos. Dan Keagamaan Islam, vol. 14, no. 2, pp. 333-361. https://doi.org/10.19105/nuansa.v14i2.1639

[35] Mardiana, L. (2016). Metode Multisensori Artikulasi terhadap Kemampuan Membaca Menulis Huruf Al-Qur'an Permulaan dengan Model At-Tartil Jilid 1 Siswa Tunarungu. J. Pendidik. Khusus, vol. 8, no. 6, pp. 1-9.

[36] Samuels, S. J. (1997). The Method of Repeated Readings. Read. Teach., vol. 50, no. 5, pp. 376-381.

[37] Mioduser, D., Tur-Kaspa, H. and Leitner, I. (2000). The learning value of computer-based instruction of early reading skills: Early reading skills. J. Comput. Assist. Learn., vol. 16, no. 1, pp. 54-63. https://doi.org/10.1046/j.1365-2729.2000.00115.x

Nunes, T., Barros, R., Evans, D. and Burman, D. (2014). Improving Deaf Children's Working Memory through Training. Int. J. Speech Lang. Pathol. Audiol., vol. 2, pp. 5166. https://doi.org/10.12970/2311-1917.2014.02.02.1

[38] Lee, J. and Yoon, S. Y. (2015). The Effects of Repeated Reading on Reading Fluency for Students with Reading Disabilities: A Meta-Analysis. J. Learn. Disabil., pp. 1-12.

[39] Marano, B. (2017). The Effects of Repeated Reading on Oral Reading Fluency of Third Grade Students. Graduate Programe in Education Goucher College, Towson, Maryland.

[40] Herlina, H., Martias, and Sumekar, G. (2013). Efektifitas Metode Al-Bayan untuk Meningkatkan Kemampuan Membaca Huruf Hijaiyah Bagi Anak Tunarungu,” J. Ilm. Pendidik. Khusus, vol. 2, no. 3, pp. 682-691.

[41] Hasan, R. O. (2016). Meningkatkan Kemampuan Mengenal Huruf Hijaiyah melalui Papan Magnetik pada Anak Tunagrahita Sedang Kelas VI SLB Karya Padang. J. Hari. Pendidik. Khusus, vol. 5, no. 2, pp. 115-125.

[42] Carver, R. P. and Hoffman, J. V. (1981). The Effect of Practice through Repeated Reading on Gain in Reading Ability Using a Computer-Based Instructional System. Read. Res. Q., vol. 16, no. 3, pp. 374-390. https://doi.org/10.2307/747408

[43] Baglama, B., Haksiz, M. and Uzunboylu, H. (2018). Technologies Used in Education of Hearing Impaired Individuals,” Int. J. Emerg. Technol. Learn. IJET, vol. 13, no. 09, pp. 53-63. https://doi.org/10.3991/ijet.v13i09.8303

[44] Rekkedal, A. M. (2012). Assistive Hearing Technologies Among Students With Hearing Impairment: Factors That Promote Satisfaction. J. Deaf Stud. Deaf Educ., vol. 17, no. 4, pp. 499-517. https://doi.org/10.1093/deafed/ens023

[45] Bagon, Š., Gačnik, M. and Istenic Starcic, A. (2018). Information Communication Technology Use among Students in Inclusive Classrooms. Int. J. Emerg. Technol. Learn. IJET, vol. 13, no. 06, pp. 56-72. https://doi.org/10.3991/ijet.v13i06.8051

[46] Singleton, J. L., Remillard, E. T., Mitzner, T. L. and Rogers, W. A. (2018). Everyday technology use among older deaf adults. Disabil. Rehabil. Assist. Technol., pp. 1-8. https://doi.org/10.1080/17483107.2018.1447609

[47] Yaman, F., Dönmez, O., Avcı, E. and Kabakçı Yurdakul, I. (2016). Integrating Mobile Applications into Hearing Impaired Children's Literacy Instuction. TED EĞITIM VE BİLIM, vol. 41, no. 188, pp. 153-174. https://doi.org/10.15390/EB.2016.6687

[48] Wauters, L. N., Tellings, A. E. J. M., van Bon, W. H. J. and Mak, W. M. (2008). Mode of Acquisition as a Factor in Deaf Children's Reading Comprehension. J. Deaf Stud. Deaf Educ., vol. 13, no. 2, pp. 175-192. https://doi.org/10.1093/deafed/enm050

[49] Nathan, S. S., Hussain, A., Hashim, N. L. and Omar, M. A. (2017). Dimensions for hearing-impaired mobile application usability model. in AIP Conference Proceedings 1891, 2017, p. 020108. https://doi.org/10.1063/1.5005441 
Paper-Accelerating Qur'an Reading Fluency Through Learning Using QUR'ANI Application ...

[50] Subhaashini, G. V. S., Divya, S., DivyaSuganya, S. and Vimal, T. (2015). Ear Hear Android Application for Specially Abled Deaf People. Int. J. Comput. Sci. Eng. Commun., vol. 3, no. 3, pp. 1108-1114.

[51] Azar, J., Saleh, H. A. and Al-Alaoui, M. A. (2007). Sound Visualization for the Hearing Impaired. Sound Vis. Hear. Impair. vol. 2, no. 1, pp. 1-7.

[52] Muhn S. H. and Jung, K. T. (2015). The Effects of Sign Language Video Location in eLearning System for the Hearing-impaired. J. Ergon. Soc. Korea, vol. 34, no. 6, pp. 597607. https://doi.org/10.5143/JESK.2015.34.6.597

[53] Cowan, N. (2014). Working Memory Underpins Cognitive Development, Learning, and Education. Educ. Psychol. Rev., vol. 26, no. 2, pp. 197-223. https://doi.org/10.1007/s10648-013-9246-y

[54] Hidayat, L., Gunarhadi. and Hidayatulloh, F. (2017). Multimedia Based Learning Materials For Deaf Students,” Eur. J. Spec. Educ. Res., vol. 2, no. 3, pp. 77-87.

[55] Muhammad, S. (2018). Application of Cognitive Theory of Multimedia Learning in Undergraduate Surgery Course. Int. J. Surg. Res. Pract., vol. 5, no. 2, pp. 1-6. https://doi.org/10.23937/2378-3397/1410065

[56] Leahy, W. and Sweller, J. (2011). Cognitive Load Theory, Modality of Presentation and the Transient Information Effect. Appl. Cogn. Psychol., vol. 25, no. 6, pp. 943-951. https://doi.org/10.1002/acp.1787

[57] Wexler, J., Vaughn, S., Edmonds, M. and Reutebuch, C. K. (2008). A Synthesis of Fluency Interventions for Secondary Struggling Readers. Read. Writ., vol. 21, no. 4, pp. $317-$ 347. https://doi.org/10.1007/s11145-007-9085-7

[58] Rasinski, T. V. (2012). Why Reading Fluency Should Be Hot! Read. Teach., vol. 65, no. 8, pp. 516-522. https://doi.org/10.1002/TRTR.01077

Baglama, B., Haksiz, M. and Uzunboylu, H. (2018). Technologies Used in Education of Hearing Impaired Individuals. International Journal of Emerging Technologies in Learning (Vol 13, No. 9), 53-63. https://doi.org/10.3991/ijet.v13i09.8303

[59] Muljono, S., Sumpeno, D., Arifianto, K., Aikawa and Purnomo, M. H. (2016). Developing an Online Self-learning System of Indonesian Pronunciation for Foreign Learners. Int. J. Emerg. Technol. Learn. IJET, vol. 11, no. 04, pp. 83-89. https://doi.org/10. 3991/ijet.v11i04.5440

[60] Munir, Setiawan, W., Nugroho, P., Kusnendar, J., Wibawa, A.W. (2018). The Effectiveness of Multimedia in Education for Spesial Education (MESE) to Improve Reading Ability and Memorizing for Children with Intellectual Disability. International Journal of Emerging Technologies in Learning (Vol 13, No. 8), 254-262. https://doi.org/10/3991/ijet.v13i08.829

[61] Chapman, M. (2003). Phonemic Awarenees: Clarifying What We Know. Lit. Teach. Learn. vol. 7, no. 1 \& 2, pp. 91-114.

[62] Shawar, B. A. (2015). Evaluating Web Accessibility of Educational Websites. Int. J. Emerg. Technol. Learn. IJET, vol. 10, no. 4, pp. 4-10. https://doi.org/10.3991/ijet.v10i4.4518

[63] Kratochwill, T., Hitchcock, J. H., Horner, R. H. and Levin, J. (2018). Single-Case Designs Technical Documentation. Research Gate.

[64] Theodorou, P. and Drigas, A. S. (2017). ICTs and Music in Generic Learning Disabilities. International Journal of Emerging Technologies in Learning (Vol. 12, No. 4), 101-110. https://doi.org/10.3991/ijet.v12i04.6588 


\section{Authors}

Yusuf Hanafi earned his bachelor degree in teaching Arabic for specific purposes from State Islamic University of Malang East Java in 2000. He received an M.Fi.I degree in Islamic thought in 2003 and an Ph.D degree in Tafser \& Hadeth in 2010 from State Islamic University of Sunan Ampel Surabaya East Java, Indonesia (email: yusuf.hanafi.fs@um.ac.id). His areas of research interest include: sociology of religions, Islam and Qur'an teaching and Arabic grammar. He is currently a lecturer of Islam \& Qur'an teaching and Arabic Grammar at the Arabic Department, Faculty of Letters, Universitas Negeri Malang (State University of Malang).

Heppy Jundan Hendrawan earned his bachelor degree in visual communication design from Universitas Negeri Malang in 2002 and received an M.Dsn degree in communication technology in 2004 from Institut Teknologi Bandung (ITB) Indonesia. His areas of research interest include: art \& design and art creation. He is currently a lecturer of art and design at Universitas Negeri Malang (State University of Malang).

Ilham Nur Hakim earned his bachelor degree in education for people with dissabilities from Universitas Negeri Malang in 2018. He is currently a postgraduate student at Universitas Negeri Malang in special education. His areas of research interest include multimedia in education for special education (MESE) and learning management system (LMS).

Article submitted 2018-11-14. Resubmitted 2018-12-22. Final acceptance 2018-12-28. Final version published as submitted by the authors. 